\title{
The Factors Affect Organizational Knowledge Creation Processes in the Egyptian Manufacturing Environment: A comparative Study
}

\author{
Dr.Abeer Osman Atallah \\ Assistant professor \\ Faculty of Commerce \\ Business Administration Department \\ Zagazig University
}




\title{
The Factors Affect Organizational Knowledge Creation Processes in the Egyptian Manufacturing Environment: a comparative Study
}

\begin{abstract}
Purpose - Individual and organizational factors are an ontological comprise a firm's climate that support initiating knowledge creation process, socialization, externalization, combination, and internalization (SECI). Thus it has a significant effect on organizational knowledge creation processes. Then SECI create knowledge in the organizations in various forms that varies between tacit and explicit, private and public knowledge; individual and organization knowledge that build organizational knowledge "epistemological" in the organization. The purpose of this study is to investigate the effect of ontological factors on organizational knowledge creation processes $(\mathrm{OKCP})$.

Methodology -Using survey approach, the data collected from 90 respondents selected from various pharmaceutical organizations, these organizations divided into three sectors according to capital size. So the research community studied three sectors of pharmaceutical organizations; big, medium, and small sector; that is to make comparisons between these sectors to define the variance between factors affect $\mathrm{OKCP}$, and the validation of OKCP in different sectors on the other hand.

Findings - This study found that individual and organizational factors "ontological" play a critical role in organizational knowledge creation processes. Individual and organizational factors have a positive impact on knowledge creation processes, and the four process of organizational knowledge creation"SECI" lead to creating organizational knowledge in the organization

Originality- This study not only contributes to knowledge creation processes by identifying a key antecedent of knowledge creation four modes but also is of importance to knowledge creation literature by demonstrating the proper effect of individual and organizational factors- as an ontological- on the processes of creating organizational knowledge.

Keywords Organizational Knowledge creation process (OKCP), individual factors; user involvement, knowledge cognition, and organizational factors.

\section{Introduction}

From the theory of knowledge creation, as proposed by Nonaka and several coauthors (Nonaka, 1994; Nonaka et al., 2000; Nonaka and Takeuchi, 1995). These authors specify four knowledge creation modes as the processes of interplay between tacit and explicit knowledge that lead to the creation of new organizational knowledge: a spiral process of socialization, externalization, combination, and internalization creates knowledge (Nonaka, 1994; Nonaka and Konno, 1998). This concept is also often referred to with the acronym SECI, resulting from the first letters of the four knowledge creation modes (Grant, 1996; Matusik and Hill, 1998; Zack, 1999.
\end{abstract}


Socialization refers to the conversion of tacit knowledge to new tacit knowledge through social interactions and shared experiences among organizational members (tacit to tacit),. Externalization refers to the conversion of tacit knowledge to new explicit knowledge (tacit to explicit). Combination refers to the creation of new explicit knowledge by merging, categorizing, reclassifying, and synthesizing existing explicit knowledge (explicit to explicit). Internalization refers to the creation of new tacit knowledge from explicit knowledge (explicit to tacit). The SECI process of knowledge creation describes dynamic interaction between tacit and explicit knowledge. OKCP enables firms to amplify knowledge embedded internally and transfer knowledge into operational activities to improve efficiency and create value (Nonaka and Konno, 1998; Nonaka et al., 2000a).

\section{Research background}

The challenge of Knowledge Management is to determine what information within an organization qualifies as "valuable."All information is not all knowledge, and not all knowledge is valuable. The key is to find the worthwhile knowledge within a vast sea of information.

\subsection{Data, Information, Knowledge, Knowledge Management, and} Organizational knowledge creation:

\subsubsection{Data}

Data is raw or discerned elements. When these elements are patterned in a certain way, data is transformed to information. Once certain rules or heuristics are applied to this information, knowledge is then created as actionable information for producing some value-added benefit.

\subsubsection{Information}

Information is a flow of messages; it is also commodity capable of yielding knowledge. Anchored on the commitment and beliefs of its holders, knowledge is created by the very flow of information (Dretske, 1981; Machlup, 1983).

\subsubsection{Knowledge}

Knowledge is the capability to act-making information actionable. The traditional epistemology defines knowledge as "justified truth belief." According to Nonaka (1994), knowledge embraces a continual dialogue between explicit and tacit knowledge which drives the creation of new concepts and ideas that are formed in the minds of individuals. According to Nonaka et al.'s definition, information becomes knowledge when it is interpreted by individuals and given a context and anchored in the beliefs and commitments of individuals. Organizations can accomplish things that individuals cannot.

So there are different types of interactional knowledge, organizational and individual knowledge; private and public knowledge; tacit and explicit knowledge.

Managers and academics have recognized knowledge as a key source of competitive advantage (Grant, 1997). Knowledge is a potentially significant resource to the firm as it may possess valuable, rare, inimitable and non-substitutable characteristics particularly if it has a tacit dimension (Polanyi, 1966; Hall and Sapsed, 2005).

Knowledge has main six characteristics, they are: 
1. Knowledge is about people. Knowledge is directly linked to what people know, and how what they know can support business and organizational objectives. It draws on human competency, intuition, ideas, and motivations. It is not a technology-based concept

2. Knowledge is orderly and goal-directed. Knowledge uses only the information that is the most meaningful, practical, and purposeful.

3. Knowledge is ever-changing. Knowledge is constantly tested, updated, revised. It is a fluid, ongoing process.

4. Knowledge is value-added. Knowledge draws upon pooled expertise, relationships, and alliances. Forums, councils, and boards can be instrumental in creating common ground and organizational cohesiveness.

5. Knowledge is visionary. This vision is expressed in strategic business terms rather than technical terms.

6. Knowledge is complementary. Knowledge can be integrated with other organizational learning initiatives such as Total Quality Management (TQM).

There are two main forms of knowledge: explicit knowledge and tacit knowledge.

\section{a. Explicit and Tacit knowledge}

Tacit and explicit knowledge are complementary, which means both types of knowledge are essential to knowledge creation. Explicit knowledge without tacit insight quickly loses its meaning. Knowledge is created through interactions between tacit and explicit knowledge and not from either tacit or explicit knowledge alone (Nonaka et al. 2000).

\section{Explicit knowledge}

Nonaka et al. (2000) and other authors such as King. Teo,(1994). Explicit knowledge is described as what can be embodied in a code or a language and as a consequence it can be verbalized and communicated, processed, transmitted and stored relatively easily. It is public and most widely known and the conventional form of knowledge which can be found in books, journals and mass media such as newspapers, television internet. It is the sort of knowledge we are aware of using and it can be shared in the form of data, scientific formulae, manuals and such like. Patents are an ideal example of explicit knowledge in a business context.

\section{Tacit knowledge}

In contrast, tacit knowledge is personal and hard to formalize - it is rooted in action, procedures, commitment, values and emotions etc. Tacit knowledge is the less familiar, unconventional form of knowledge. It is the knowledge of which we are not conscious. Tacit knowledge is not codified, it is not communicated in a "language", it is acquired by sharing experiences, by observation and imitation (Kikoski and Kikoski, 2004; Hall and Andriani, 2002).

Many definitions of tacit knowledge exist but Polanyi (1966) is widely accepted as the founding father that identified the significance of the concept of tacit knowledge. Polanyi encapsulates the essence of tacit knowledge in the phrase "we know more than we can tell', and provides further clarification in such commonplace examples 
as the ability to recognize faces, ride a bicycle or ski, without the slightest idea to explain how these things are done (Polanyi, 1966).

\section{Tacit knowledge dimensions}

Nonaka (1991) described that there are two dimensions of tacit knowledge:

- The first is the technical dimension which encompasses the "know-how",

- The second is the cognitive dimension which consists of beliefs, ideas and values which we often take for granted"' (Nonaka and Konno, 1998).

\section{Tacit knowledge components}

Tacit knowledge embodies the following items:

-an individual's education,

-natural talent,

-Experience and judgment, e.g. an experienced venture capitalists.

\section{Tacit knowledge importance}

Tacit knowledge is critical as it enables (Choi, Byounggu and Lee, Heeseok . 2002):

- creating new knowledge,

-generating new products

-and improving new business procedures.

Thus tacit knowledge can be gained both in and outside the organization. Inside the organization, by deciding what existing tacit knowledge capabilities the members in the organization carry themselves and what improvement could be made to build up the accumulated learning of the individuals and, therefore, enhance the tacit knowhow competence. Outside the organization, by trying to gain tacit knowledge and skills from other firms, through recruiting the right individuals with the requisite education or work experience, by acquiring parts of or whole new companies, by engaging appropriate consultants or by building networks with other companies. It is made clear that tacit knowledge is gained and vitalized throughout all functions and stages of a company's operation King. Teo,(1994).

\section{b. Individual and organizational knowledge}

\section{Individual knowledge:}

Individual knowledge represents a personal ability to take action that can distinguish himlher from others and afford him $\backslash$ her competitive advantage (Mortazavi and Bahrami, 2012). An individual's knowledge may be the key resource that distinguishes a firm. Individual knowledge is composed of both tacit and explicit knowledge (Foster and Franz, 1999).

\section{Organizational knowledge:}

Organizational knowledge represents a firm's ability to take action that can distinguish it from competitors and afford competitive advantage (Leonard-Barton, 1998). Accordingly, a firm's knowledge may be the key resource that distinguishes a firm. Organizational knowledge is composed of both public and private knowledge.

\section{c. Public and Private Knowledge \\ Public knowledge}

Public knowledge resides in public domain. It includes knowledge not unique to any one firm. It is also a kind of public goods. Public knowledge contain component that is held individually. It also represents industry and occupational best practice. Since it is not unique or proprietary to any one firm and easily available. Public knowledge cannot be a source of competitive advantage, but the failure to apply 
public knowledge within the organization can be a disadvantage to the organization's competitive position. The application of public knowledge relating to best practice will not promise competitive advantage, but it is necessary for survival in competitive environment (Matusik\& Hill, 1998).

\section{Private knowledge}

Private knowledge is composed of both component and architectural knowledge, whereas public knowledge is composed of only component knowledge. Component elements are those developed internally and not yet to leak out to public domain. Architectural knowledge is organization-wide knowledge that is collectively held, tacit and private. No two organizations have the same architectural knowledge. Private knowledge includes an organization's unique routines, process, documentation, or trade secrets Matusik\& Hill, 1998).

Both categories of knowledge are valuable if they can be successful applied to value-creating tasks (Ichijo, 2002). Private knowledge is distinctive to organization. It is a valuable, rare, inimitable and non-substitutable resource and a source of competitive advantage for organizations.Fig.1 displays the structure of organizational knowledge.

\section{Organizational knowledge}

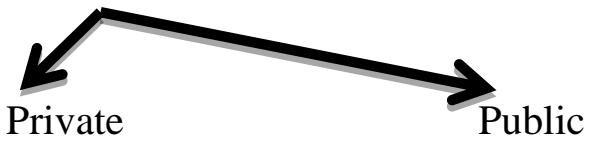

Private

Public

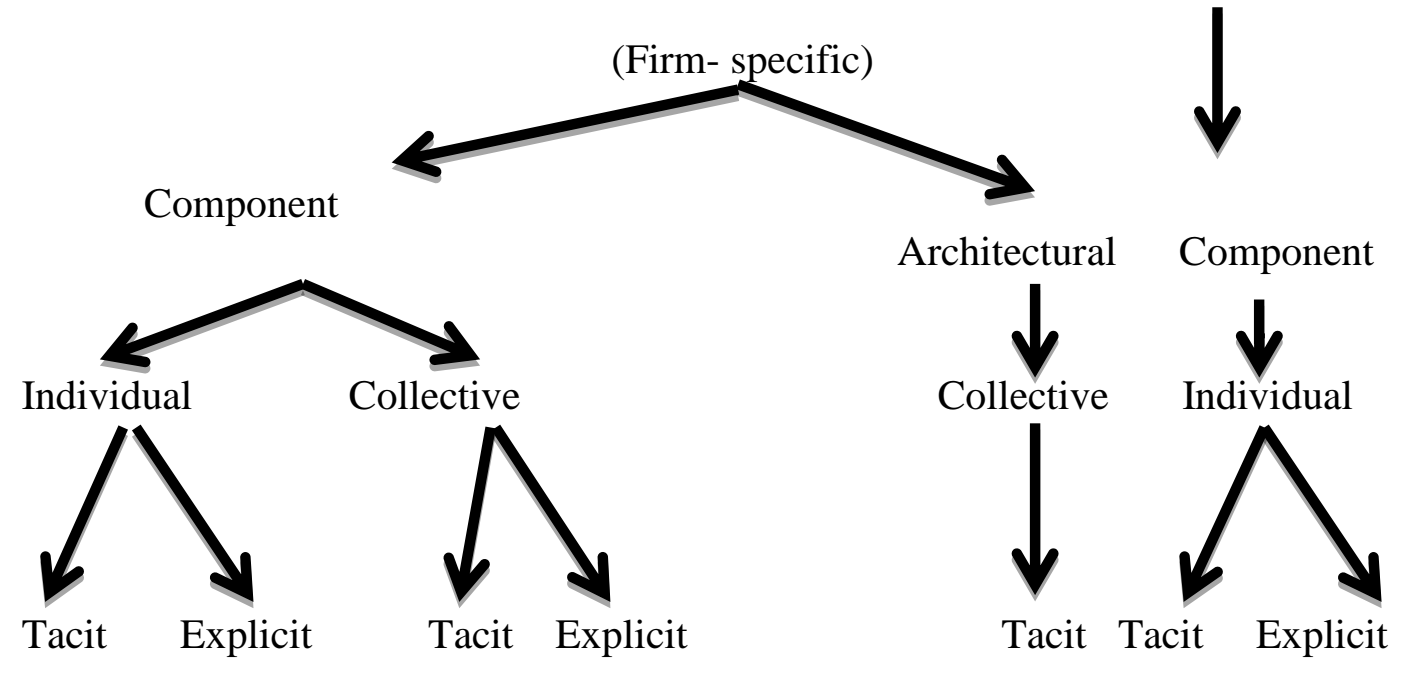

Fig.1 structure of organizational knowledge

Source: Yang, C.W.et.al.,2010.

\section{Knowledge life cycle}

Fig.2 has shown knowledge life cycle; that illustrated six stages to knowledge life cycle.

- Create: knowledge must be created either within or outside the organization. This is typically comprised of iterative tacit and explicit loops until the knowledge is ready for distribution to those outside the creating group.

- Store: knowledge can then be stored somewhere, either tacitly or explicitly so that it is accessible for others to find and use. 
- Find: who need the specific knowledge must then findout where it is, when they need it, by searching in the right places and / or asking the right people.

- Acquire: Once the knowledge source is found, the user will then go through the act of actually acquiring it. This will involve gaining personal knowledge from other humans or documented sources.

- Use: Once acquired, the knowledge can be put to use towards some productive purpose.

- Learn: having been used, perhaps repeatedly, the user will learn what worked well and not so well as a result of applying the knowledge gained. This can then be taken as significant input into further iterations of the knowledge creation and distribution process.

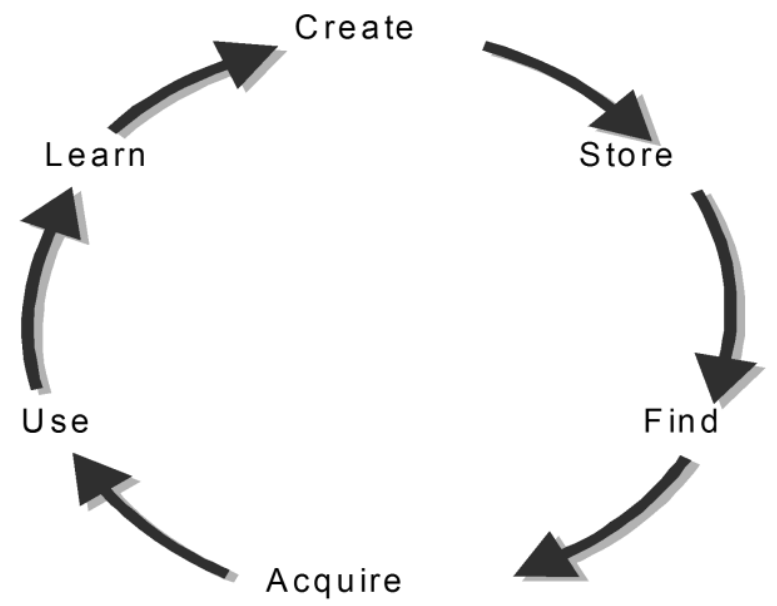

Fig.2 Knowledge life cycle

Thus knowledge Management is the management of this cycle for optimal performance across all aspects of the Knowledge six stages.

\section{Dimensions of knowledge}

There is considerable debate in the literature regarding various types and dimensions of knowledge. In particular, the distinction between tacit and explicit knowledge receives substantial attention. Tacit knowledge is that held in the minds of individuals, while explicit knowledge is that externalized and shared with others. It has been suggested that there are four modes of interaction between these two forms of knowledge:

(1) From tacit knowledge to tacit knowledge: the process of 'socialization' through shared experience and interaction. Socialization yields new tacit knowledge that is built through informal interaction, i.e., through an exchange of tacit knowledge. It occurs by spending time together, making joint hands on experiences, working in the same environment, and in informal social meetings (even outside the workplace) between members of an organization.

(2) From tacit knowledge to explicit knowledge: the process of 'externalization' using metaphors and figurative language. Combination refers to the process by which sense is made of the relations between previously unrelated knowledge domains. It involves collecting, editing, sorting, and synthesizing existing explicit knowledge and subsequently disseminating the new knowledge. 
(3) From explicit knowledge to explicit knowledge: the process of 'combination' through reconfiguring existing knowledge (such as sorting, adding, re-categorizing, and conceptualizing explicit knowledge) can lead to new knowledge externalization is an act of codifying or converting tacit knowledge into explicit knowledge, characterized by more formal interactions such as expert interviews or the sharing of lessons learned in a previous project.

(4) And from explicit knowledge to tacit knowledge: the process of internalization through the learning process. (Polanyi, 1966). Internalization is the process of applying explicit knowledge, thereby absorbing, embodying, and converting it into individually held tacit knowledge. This can be done by either experiencing i.e., by day-to-daywork, or by experimenting i.e., trial-and-error activities or guided testing (Kale and Singh, 1999; Nonaka et al. ).

\subsubsection{Knowledge Management (KM)}

Knowledge management is the process of creating value from an organization's intangible assets. Simply put, knowledge management deals with how best to leverage knowledge internally and externally. Many definitions of knowledge management appear in the extant literature. According to Davenport \&Prusak, 1998 knowledge management draws from existing resources that the organization may already have in place - good information systems management, and human resource management practices. Zack M. (1999). defined knowledge management as any processes or practice of creating, acquiring, capturing, sharing, and using knowledge, wherever it resides, to enhance learning and performance in organizations. According to Tsai, 2007 knowledge management is the identification, storage, protection of knowledge for future operational and strategic benefit of the organization; this Knowledge management is the process of creating value from an organization's intangible assets .

Knowledge management is a business activity with two primary aspects:Treating the knowledge component of business activities as an explicit concern of business reflected in strategy, policy, and practice at all levels of the organization; and, making a direct connection between an organization's intellectual assets-both explicit (recorded) and tacit (personal know-how) — and positive business results. Knowledge management is a collaborative and integrated approach to the creation, capture, organization, access and use of an enterprise's intellectual assets. (Gray, 2000)

So from the cognitive science or knowledge science perspective: Knowledge - the insights, understandings, and practical know-how that we all possess-is the fundamental resource that allows us to function intelligently. Over time, considerable knowledge is also transformed to other manifestations-such as books, technology, practices, and traditions-within organizations of all kinds and in society in general. These transformations result in cumulated expertise and, when used appropriately, increased effectiveness. Knowledge is one, if not THE, principal factor that makes personal, organizational, and societal intelligent behavior possible. (Wiig, 1993, pp. 38-39).

And, from the process/technology perspective:Knowledge management is the concept under which information is turned into actionable knowledge and made available effortlessly in a usable form to the people who can apply it. (Information Week, Sept. 1, 2003). 
On the basis of knowledge life cycles, KM cycle can be distilled, According to Kahlil Gibran(2004) three major stages Knowledge capture and/or creation; Knowledge sharing and dissemination, Knowledge acquisition and application. Liebowitz and Megbolugbe (2003) determined four stages for cycle: capture, sharing, application, and knowledge creation. Martensson (2000) represented another four stages for KM cycle: collecting information, sorting information, making information available, and use the information. The researcher found according to extant literature that KM cycle begins with creation, then retention, transfer, utilization, and finally end with organizational memory.

Knowledge creation $(K C)$ means create knowledge by generating new products or services. Knowledge retention means establishing policies for managing knowledge and quality standards for knowledge work. Transfer knowledge means create knowledge-related capabilities shared across enterprise, Support enterprise strategy and direction by facilitating effective communication to all. Utilization knowledge means align knowledge strategies and tactics with enterprise direction and facilitate and monitor knowledge management-related activities and programs. Organizational memory refers to stored information that can be brought to bear on present decisions (Lee, Wei-Long et.al.2011). Furthermore, Chang et.al, (2011) asserted that organizational memory is not stored centrally but distributed across different retention facilities. Effective organizational memory enables businesses to avoid past mistakes, to ensure the continued use of best practices, and to draw on the collective wisdom of its past and present employees. Consequently, organizational memory is a tool for knowledge management.

Thus KM adds the following value:

- Creating collaboration where knowledge can be created and shared, that can act as a catalyst for decisions and actions in order to maximize opportunities.

- Retaining knowledge created and shared through collaboration and making it available for reuse later in a different context.

- Mining of internal business information and external information and turning it into knowledge through the use of knowledge management tools.

- Increasing individual, team and organizational efficiency.

- Centralizing access to knowledge.

\subsubsection{Organizational knowledge creation $(O K C)$}

Organizational knowledge creation is "the capability of a company as a whole to create new knowledge, disseminate it throughout the organization and embody it in products, services, and systems" (Nonaka \& Takeuchi, 1995, p. 3).

\subsection{Factors affect OKCP}

Nonaka and Takeuchi (1996) proposed a research framework to describe knowledge creation processes. This framework contains two dimensions: epistemological and ontological. The first stands for the characteristics of knowledge, which distinguish tacit and explicit knowledge, and the key to knowledge creation lies in the mobilization and conversion of tacit knowledge. They argued that knowledge is created through the interaction and intersection between tacit and explicit knowledge, following four different modes of conversion: socialization, externalization, combination, and internalization, i.e. the SECI processes. The second dimension of Nonaka and Takeuchi's framework is ontological, which is concerned with the levels 
of knowledge-creating entities or mechanisms that may initiate the SECI processes such as individuals and organizations. In order to create knowledge effectively.

Since Nonaka and Takeuchi only provided a theoretical framework for acquiring and converting knowledge, they did not identify the effect degree of ontological dimensions on OKCP. This study aims to identify the degree of ontological dimensions affectedness.

\section{Ontological Dimensions}

Ontological concerned with the levels of knowledge-creating entities or mechanisms that may initiate the SECI processes such as individuals and organizations. In order to create knowledge effectively.

\section{A. Individual factors}

Information becomes knowledge when it is interpreted by individuals and given a context and anchored in the beliefs and commitments of individuals. Although Nonaka and Takeuchi (1996) and Nonaka et al(2000) provided a rich conceptualization of knowledge creation from the individual perspective, they did not identify concrete guidelines for enabling knowledge creation. Thus, this study examined two types of characteristics concerning individuals may have an impact on knowledge creation: user involvement and cognition of knowledge Chou, Shih-Wei and Tsai, Yu-Hung ( 2004).

\section{A.1.User involvement}

User involvement refers to a psychological state reflecting the importance and personal relevance of a new information system (IS) to the user. User involvement composed of analysis and design stage and implementation stage; each stage has its factors to accomplish user involvement process (Foster and Franz, 1999; Langton et.al., 2003). Thus, user involvement may have an impact on knowledge creation. Table 1.displayed user involvement's factors.

Table 1.

User involvement's factors

\begin{tabular}{|l|l|}
\hline \multicolumn{1}{|c|}{ Factors of analysis and design stage } & \multicolumn{1}{|c|}{ Factors of implementation stage } \\
\hline User Clarifies Information Needs & Task usefulness \\
\hline User Specifies Input Requirements & User Actually Uses System \\
\hline User Clarifies Output Requirements & Assists User in Performing Job Better \\
\hline Analyst Leads Questions and Answers & $\begin{array}{l}\text { Users Actually Use Output or Reports from } \\
\text { System }\end{array}$ \\
\hline $\begin{array}{l}\text { Analyst Responsible for Satisfying } \\
\text { Needs }\end{array}$ & $\begin{array}{l}\text { System Provides Reports Almost Exactly } \\
\text { Needed }\end{array}$ \\
\hline $\begin{array}{l}\text { User Influences System Planning and } \\
\text { Design }\end{array}$ & $\begin{array}{l}\text { Understanding System in Assisting with Job } \\
\text { Tasks }\end{array}$ \\
\hline User Clarifies Information Needs & User Actually Uses System \\
\hline User Specifies Input Requirements & General attributes \\
\hline User Clarifies Output Requirements & User Data from System Requires Correction \\
\hline Analyst Leads Questions and Answers & $\begin{array}{l}\text { System Overloads User with More Data than } \\
\text { Can be Used }\end{array}$ \\
\hline $\begin{array}{l}\text { User Influences Technical } \\
\text { Development }\end{array}$ & $\begin{array}{l}\text { System Troublesome of Difficult to Obtain } \\
\text { Information }\end{array}$ \\
\hline
\end{tabular}




\begin{tabular}{|l|l|}
\hline User Influences System Testing & $\begin{array}{l}\text { User Would Like System Modified or } \\
\text { Redesigned }\end{array}$ \\
\hline
\end{tabular}

Source: developed by the researcher depending on Foster and Franz, 1999; Langton et.al. 2003.

\section{A.2. Cognition of knowledge}

Another individual factors is cognition of knowledge. Huber argued (1991), that only when individuals are cognitively willing to 'search and notice' do they begin to appreciate the value and usefulness of knowledge. King and KO (2001) also contended that cognition is the most fundamental and important part of initiating knowledge creation. All the subsequent knowledge management processes, such as $\mathrm{KC}$, retention, transfer, utilization, and organizational memory have their roots in cognition.

\section{B. organizational factors}

From the organizational perspective according to the theory proposed by Nambisan et al. (1999), appropriate organizational design and activities may influence the result of knowledge creation. Therefore, organizations might adopt appropriate managerial interventions to facilitate knowledge creation.

Table2. Shown the features of individual and organizational factors and their relationship with tacit and explicit knowledge (Choi,Byounggu and Lee, Heeseok 2002).

Table 2.

The features of individual and organizational factors and their relationship with tacit and explicit knowledge

\begin{tabular}{|c|c|c|}
\hline Items & Individual factors & Organizational factors \\
\hline Features & $\begin{array}{l}\text { Emphasize dialogue through } \\
\text { social networks and person-to- } \\
\text { person contacts } \\
\text { Focus on acquiring knowledge } \\
\text { via experienced and skilled } \\
\text { people } \\
\text { Attempts made to share } \\
\text { knowledge informally }\end{array}$ & $\begin{array}{l}\text { Emphasize codified knowledge } \\
\text { in knowledge management } \\
\text { processes } \\
\text { Focus on codifying and storing } \\
\text { knowledge via information } \\
\text { technology } \\
\text { Attempts made to share } \\
\text { knowledge formally }\end{array}$ \\
\hline $\begin{array}{l}\text { Tacit } \\
\text { knowledge }\end{array}$ & $\begin{array}{l}\text { Community of practice, } \\
\text { discussion group, and help task } \\
\text { Emphasize person-to person }\end{array}$ & $\begin{array}{l}\text { Create networks through IT } \\
\text { (video conferencing, groupware, } \\
\text { and virtual reality) } \\
\text { Facilitate face-to-face meeting }\end{array}$ \\
\hline $\begin{array}{l}\text { Explicit } \\
\text { knowledge }\end{array}$ & $\begin{array}{l}\text { Help transmit newly created } \\
\text { concepts } \\
\text { Breakdown of concepts using } \\
\text { face-to-face meeting (usually in } \\
\text { Japanese } \\
\text { firms) }\end{array}$ & 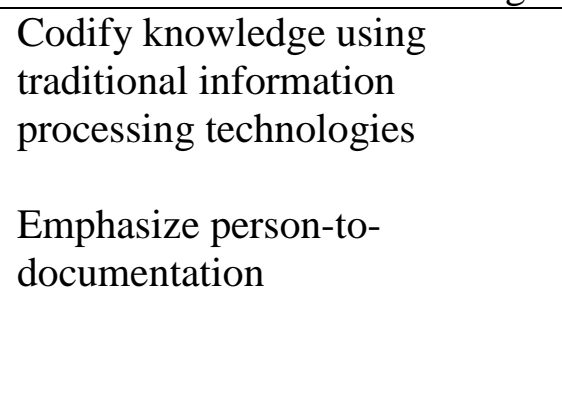 \\
\hline
\end{tabular}

Source: developed by the researcher depended on (Choi, Byounggu and Lee, Heeseok2002 


\subsection{OKCP (SECI model)}

OKCP consists of four modes that are known as SECI. The SECI process of KC describes dynamic interaction between tacit and explicit knowledge. Knowledge creation process enables firms to amplify knowledge embedded internally and transfer knowledge into operational activities to improve efficiency and create value (Nonaka and Konno, 1998; Nonaka et al., 2000a).

\subsubsection{Socialization}

Socialization is the process of converting tacit knowledge held by individuals through shared experiences. Frequently social interactions and perceptions help organizational members share mental modes and experiences (Nonaka et al., 2000b). Employees empathize with colleagues to exchange a variety of knowledge for their work and problem-solving (Becerra- Fernandez and Sabherwal, 2001). In socialization, companies can converge and amplify tacit knowledge, which diminishes barriers between individuals (Nonaka et al., 2000a).

\subsubsection{Externalization}

The externalization process articulates tacit knowledge into explicit knowledge. When tacit knowledge is converted to explicit knowledge, employees easier understand the contents of knowledge. Externalization facilitates employees to express images or ideas as substantial concepts and notions that are needed for new product innovation and development.

\subsubsection{Combination process}

The combination process converts explicit knowledge into more complex and systematic explicit knowledge (Nonaka et al., 2000b). Employees integrate and disseminate the newly explicit knowledge at the organizational level. Firms can use the combination process to create new knowledge from existingknowledge and generate new knowledge applications (Nonakaet al., 2000a). New knowledge and skill will enhance the firm's ability to introduce new products and services, or improve existing ones more efficiently, thereby reducing redundancies and costs (Gold et al., 2001; Grant, 1996; Lee and Choi, 2003).

\subsubsection{Internalization process}

The internalization process embodies explicit knowledge into tacit knowledge. Through internalization, employees transform knowledge into organizational memories and realize knowledge in practical operations such as new product development or manufacturing procedures (Nonaka et al., 2000b). The firm utilizes its human capital to transfer tacit knowledge, which becomes the base for further innovation and new routine (Kogutand Zander, 1992; Nonaka et al., 2000a; Lee and Choi, 2003). Fig.3 displayed the relationship between SECI process and knowledge creation. 


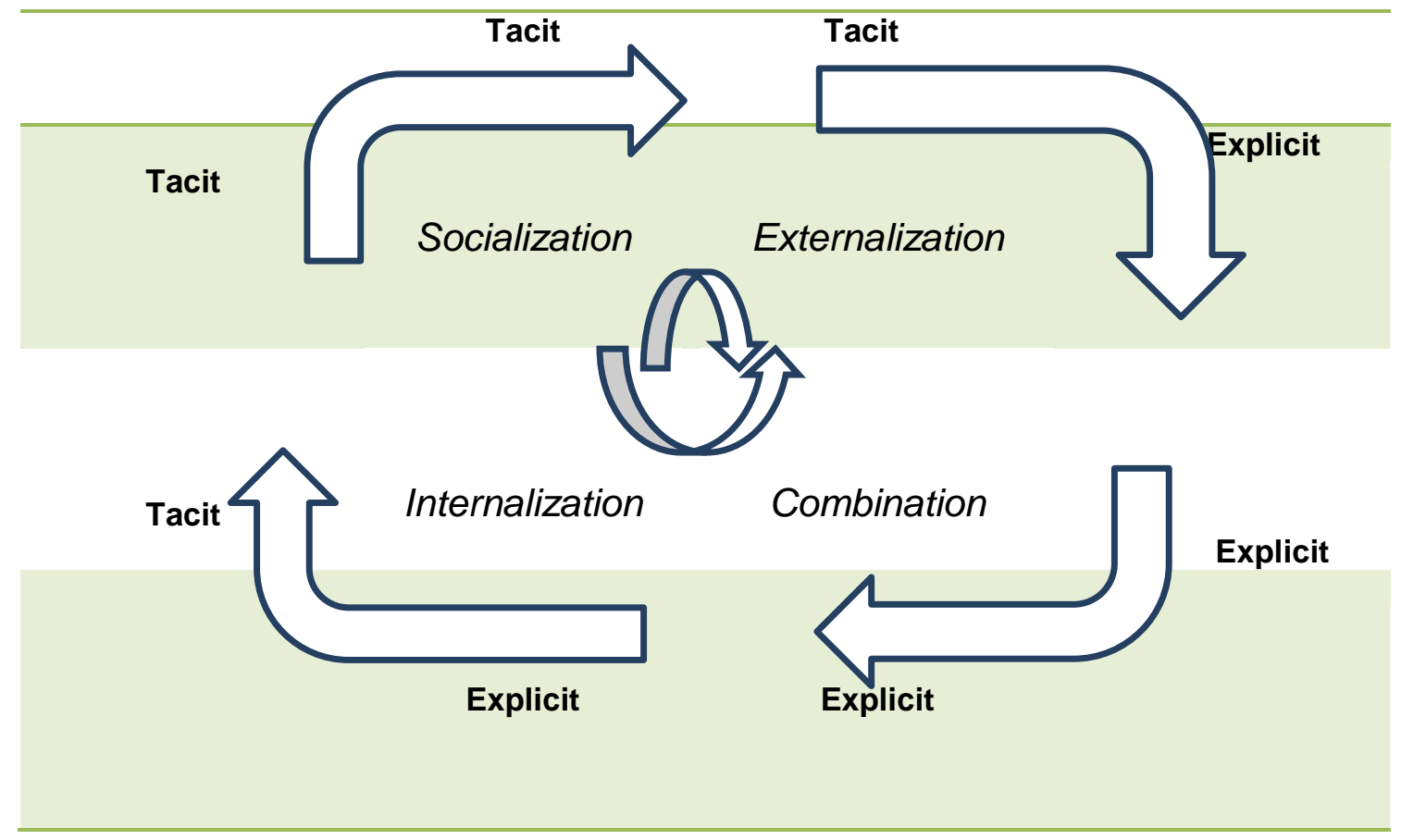

Fig.3

The relationship between SECI process and knowledge creation

Source: Developed by the researcher according to Kogut and Zander, 2003; Nonaka et al., 2000a; Lee and Choi, 2003; Chou and Tsai,2004.

Thus, the SECI model of knowledge creation transforms knowledge into business values and results in organizational effectiveness, improvement, and innovation (Nonaka et al., 2000b; Lee and Choi, 2003).

Knowledge created through the SECI model triggers a new spiral of knowledge creation, as:

1- Firms transcend organizational boundaries to transfer and utilize knowledge embedded in customers or suppliers (Nonaka et al., 2000b).

2- Such knowledge conversion allows firms to create new knowledge and develop new products at a lower cost and more speedily than competitors do (Droge et al., 2003).

3- Thus, knowledge creation provides an opportunity for firms to enhance efficiency and sustain competitive advantages (Chia, 2003; Nonaka et al., 2000a).

4- If the firm attains a higher level of knowledge creation process, this will lead to a higher level of performance. Table 3.SECI operational definition. 
Table 3.

SECI operational definition

\begin{tabular}{|l|l|}
\hline Variables & Operational definition \\
\hline Socialization & $\begin{array}{l}\text { Degree of : } \\
\text { Tacit knowledge accumulation } \\
\text { Extra-firm social information collection } \\
\text { Intra-firm social information gathering } \\
\text { Transfer of tacit knowledge }\end{array}$ \\
\hline Externalization & $\begin{array}{l}\text { Degree of: } \\
\text { Creative dialogue } \\
\text { Deductive and inductive thinking } \\
\text { Use of metaphors } \\
\text { Exchanging ideas }\end{array}$ \\
\hline Combination & $\begin{array}{l}\text { Degree of: } \\
\text { Acquisition and integration } \\
\text { Synthesis and processing } \\
\text { Dissemination }\end{array}$ \\
\hline Internalization & $\begin{array}{l}\text { Degree of: } \\
\text { Personal experiences } \\
\text { Simulation and experimentation }\end{array}$ \\
\hline
\end{tabular}

Source: Developed by the researcher ,according to Nonaka and Takeuchi (1995) and Nonaka et al. (2000), Bierly and Chakrabarti (1996), Bohn (1994), Hansen et al. (1999), Jordan and Jones (1997), Swan et al. (1999) and Zack (1999a).

\section{The development of hypotheses}

According to Nonaka et al.'s (1996) theory, the roles played by individuals are the fundamental part of knowledge creation, because knowledge is created through the interactions among individuals or between individuals and their environments. Although the roles of technology users as a source of knowledge creation and creativity have been acknowledged in the literature (Ciborra1991; Nambisan et al. 1999) little research has examined the roles of individuals and organization facilitating knowledge creation. Individuals' roles - user involvement and cognition of knowledge.

Therefore, this study examines the effect of individual and organizational factors on knowledge creation. According to this examination this study identified two critical aspects concerning individual perspectives that initiate facilitating knowledge creation - user involvement and user cognition. The term user involvement has been used in a variety of fields to describe a subjective psychological state reflecting the importance and personal relevance of an issue (Sherif et al. 1965 ) such as an advertisement or product (Krugman 1967 ), and an individual's job (Lawler and Hall 1970). In a system development context, user involvement should refer to a psychological state reflecting the importance and personal relevance of a new system to the user (Barki and Hartwick 1994).The first hypothesis is:

Hypothesis 1: There are statistically significant differences between the validation degrees of validation of ontological factors between organizations 'sectors. 
According to King and Ko's(1994) theory, cognition plays a critical role in initiating knowledge management. They propose a framework that specifies the possible stages where knowledge creation occurs. These stages include cognition, post-cognition, organization related actions by the acquirer, diffusion, infusion, thoroughness, organization related actions by others, and organization performance. King and Ko also argued that individuals' cognition of knowledge plays a critical role in facilitating organization performance. In addition, only when individuals are cognitively willing to 'search and notice' (Cohen and Levinthal 1990 ; Huber 1991 ). Then, knowledge creation is possible. Therefore, individuals' cognition of knowledge is the fundamental part of knowledge creation.

Organizations with more cognition of knowledge usually realize the importance of knowledge, thus are more willing to share, adopt, and analyze knowledge. As a result, such organizations achieve knowledge creation more effectively and usually acquire better organization performance. Thus, second hypothesis is:

Hypothesis 2: There are statistically significant differences between the degrees of validation of organizational knowledge creation processes OKCP between organizations' sectors.

In Nambisan et al.'s research (1999), organizational factors are defined as a structural arrangement or a variety of design actions to facilitate interactions and knowledge exchange among organizational members. Empirical studies also indicate that organizational factors concerning learning and knowledge acquisition can exhibit differential efficacy with regard to KC.

Organizational factors provide awareness of working practices. Although the roles played by the aforementioned organizational factors in promoting interaction and knowledge transfer is widely acknowledged, no empirical research specifically investigates how effective organizational factors are in facilitating the organizational knowledge creation process. Thus, the third hypothesis is:

Hypothesis 3: There is a probability to have a significant correlation relationship between ontological factors and OKCP; socialization, externalization, combination, and internalization in various organizations sectors.

Finally, in order to examine the effect on knowledge creation processes in a comprehensive perspective, This study considered the composite effect of the aforementioned variables on organizational knowledge creation process. The last hypothesis is:

Hypothesis 4: There is a probability to be an ontological factors impact on OKCP in various organizations' sectors.

\section{Method}

\section{Samples and data collection}

This study employed a questionnaire survey approach to collect data, and all items required five-point Likert-style responses ranged from $1=$ "strongly disagree, "through $3=$ "neutral, "to $5=$ "strongly agree."The study population is represented in 90 who work in MIS and IT units in the firms listed in the El-Asher Mn Ramadan city that working in phamaceutical products. This study categorized firms into three 
sectors according to firms' capital: big sector: capital scale more than one milliard pounds, medium sector capital is more than 750.000 pounds, finally and small sector capital is less than 750.000 pounds. 90 questionnaires had delivered; 20 to big sector, 30 to medium sector, and 40 to the small sector. Researcher received all questionnaires. Within each sector, this study measured factors affect initiating organizational knowledge creation processes and the validity of OKCP in research community.

\section{Measures}

Researcher measured Ontological variables that affect initiating OKCP as independent variable, and also measured the component of SECI as dependent variables.

To initiate OKCP "Organizational Knowledge creation process", Ontological factors" internal environment factors" must be available in two forms: The first form is individual factors which include user involvement and knowledge cognition, the second form is organizational factors which consist of task understanding factors and information understanding factors.

User involvement can be achieved through two stages; analysis and design stage which requires specifying the information needs to deal with the input and output of tasks in work, also this stage demand a user role to influence planning and design the information needs, technical development, and system testing.

The second stage to achieve user involvement is implementation stage which contains user's task usefulness and user's general attributes.

Knowledge cognition is the second part of individual factors that influence the initiating of $\mathrm{OKCP}$. Knowledge cognition determined that user involvement needs a degree of some factors to be available: user comfort with IT tools, user able to collect knowledge, user can share experience and knowledge, user able to innovate solutions to new and old problem.

After initiating organizational knowledge creation process $\mathrm{OKCP}$, the processes will be initiated in four stages; socialization, externalization, combination, and internalization which are known with the acronym SECI.

Researcher measured ontological factors by building a questionnaire to measure these factors as displayed in table 4. 
Table 4

Ontological factors affect OKCP

\begin{tabular}{|c|c|c|c|c|c|}
\hline \multicolumn{6}{|c|}{ Ontological factors \Internal environment } \\
\hline \multicolumn{4}{|c|}{ Individual Factors } & \multicolumn{2}{|c|}{ Organizational Factors } \\
\hline \multicolumn{3}{|c|}{ User Involvement } & Knowledge & \multirow{3}{*}{ 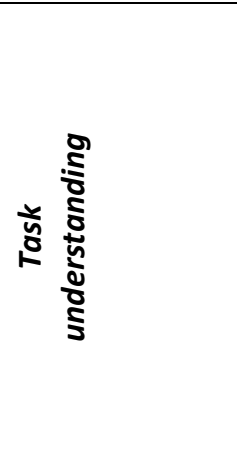 } & \multirow{3}{*}{ 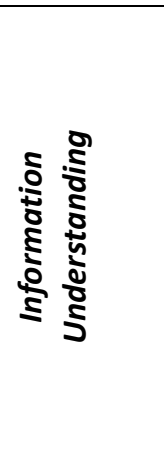 } \\
\hline \multirow{2}{*}{$\begin{array}{c}\text { Analysis } \\
\text { and } \\
\text { Design stage }\end{array}$} & \multicolumn{2}{|c|}{ Implementation stage } & & & \\
\hline & 蒙 & 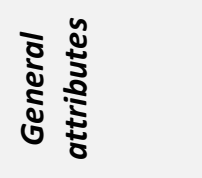 & & & \\
\hline User Clarifies Information Needs & $\begin{array}{l}\text { User } \\
\text { Actually } \\
\text { Uses } \\
\text { System }\end{array}$ & $\begin{array}{l}\text { User Data } \\
\text { from } \\
\text { System } \\
\text { Requires } \\
\text { Correction }\end{array}$ & $\begin{array}{l}\text { User comfort } \\
\text { with IT tools }\end{array}$ & Degree of: & Degree of: \\
\hline $\begin{array}{l}\text { User Specifies Input } \\
\text { Requirements }\end{array}$ & $\begin{array}{l}\text { Assists User } \\
\text { in } \\
\text { Performing } \\
\text { Job Better }\end{array}$ & $\begin{array}{l}\text { System } \\
\text { Overloads } \\
\text { User with } \\
\text { More Data } \\
\text { than Can be } \\
\text { Used }\end{array}$ & $\begin{array}{l}\text { User able to } \\
\text { collect } \\
\text { knowledge }\end{array}$ & $\begin{array}{l}\text { Knowledge } \\
\text { codification }\end{array}$ & $\begin{array}{l}\text { Knowledg } \\
\text { e } \\
\text { acquisition } \\
\text { from } \\
\text { experts and } \\
\text { co-workers }\end{array}$ \\
\hline $\begin{array}{l}\text { User Clarifies Output } \\
\text { Requirements }\end{array}$ & $\begin{array}{l}\text { Users } \\
\text { Actually } \\
\text { Use Output } \\
\text { or Reports } \\
\text { from } \\
\text { System }\end{array}$ & $\begin{array}{l}\text { System } \\
\text { Troublesom } \\
\text { e of } \\
\text { Difficult to } \\
\text { Obtain } \\
\text { Information }\end{array}$ & $\begin{array}{l}\text { User can } \\
\text { share } \\
\text { experience } \\
\text { and } \\
\text { knowledge }\end{array}$ & Documentation & $\begin{array}{l}\text { Face-to- } \\
\text { face help } \\
\text { by experts }\end{array}$ \\
\hline $\begin{array}{l}\text { Analyst Leads Questions and } \\
\text { Answers }\end{array}$ & $\begin{array}{l}\text { System } \\
\text { Provides } \\
\text { Reports } \\
\text { Almost } \\
\text { Exactly } \\
\text { Needed }\end{array}$ & $\begin{array}{l}\text { User Would } \\
\text { Like System } \\
\text { Modified or } \\
\text { Redesigned }\end{array}$ & $\begin{array}{l}\text { User able to } \\
\text { innovate } \\
\text { solutions to } \\
\text { new and old } \\
\text { problem. }\end{array}$ & $\begin{array}{l}\text { Knowledge } \\
\text { acquisition in } \\
\text { codified forms }\end{array}$ & $\begin{array}{l}\text { Knowledg } \\
\text { e } \\
\text { acquisition } \\
\text { by one-to- } \\
\text { one } \\
\text { mentoring }\end{array}$ \\
\hline $\begin{array}{l}\text { Analyst Responsible for } \\
\text { Satisfying Needs }\end{array}$ & $\begin{array}{l}\text { Understands } \\
\text { System in } \\
\text { Assisting } \\
\text { with Job } \\
\text { Tasks }\end{array}$ & & & $\begin{array}{l}\text { sharing through } \\
\text { codified forms }\end{array}$ & $\begin{array}{l}\text { Informal } \\
\text { dialogues } \\
\text { for } \\
\text { knowledge } \\
\text { sharing }\end{array}$ \\
\hline \multicolumn{6}{|l|}{$\begin{array}{l}\text { User Influences System Planning } \\
\text { and Design }\end{array}$} \\
\hline \multicolumn{6}{|l|}{$\begin{array}{l}\text { User Influences Technical } \\
\text { Development }\end{array}$} \\
\hline User Influences System Testing & & & & & \\
\hline
\end{tabular}

Source: developed by researcher depending on: Schulzea ,Anja and Hoegl , Martin, (2008).", Foster and Franz, 1999 ; Lang., 2001. 
So ontological factors have two main dimensions represented in individual and organizational factors. As well as Ontological factors initiate OKCP that are SECI, researcher measured the degree of the four process available in the study society by building a questionnaire measured the following four dimensions as shown in table .

Table 5

OKCP dimensions

\begin{tabular}{|c|c|}
\hline Process & Factors \\
\hline \multirow[t]{4}{*}{ S: Socialization } & $\begin{array}{l}\text { 1. The use of apprentices and mentors to transfer } \\
\text { knowledge }\end{array}$ \\
\hline & 2.Employees rotation across areas \\
\hline & 3. Cooperative projects across directorates \\
\hline & $\begin{array}{l}\text { 4. common understanding of a problem with people from } \\
\text { other departments in the company. }\end{array}$ \\
\hline \multirow[t]{4}{*}{ E:Externalization } & 1.Capture and transfer of experts' knowledge \\
\hline & 2. Groupware and other team collaboration tools \\
\hline & 3.Chat groups/Web-based discussion groups \\
\hline & $\begin{array}{l}\text { 4. Express and model tacit knowledge by metaphors and } \\
\text { analogies }\end{array}$ \\
\hline \multirow[t]{4}{*}{ C:Combination } & $\begin{array}{l}\text { 1. Repositories of information, best practice, and lessons } \\
\text { learned }\end{array}$ \\
\hline & 2. Web pages (Intranet and Internet) \\
\hline & 3. Web-based access to data \\
\hline & 4. Databases and knowledge base \\
\hline \multirow[t]{4}{*}{ I: Internalization } & 1. Learning by doing \\
\hline & 2. Learning by observation \\
\hline & $\begin{array}{l}\text { 3. Face-to-face meetings to share knowledge and } \\
\text { experience }\end{array}$ \\
\hline & 4. On-the-job training \\
\hline
\end{tabular}

Source: Chou, Shih-Wei and He, Mong-Young. (2004).

So this research has six main dimensions: individual factors, organizational factors, socialization, externalization, combination, and internalization. 


\section{Analysis and results}

Table 6 illustrated the validation degree of Ontological Factors in research community.

Table No.6

The validation degree of Ontological Factors in research community

\begin{tabular}{|c|c|c|c|c|c|c|c|c|c|}
\hline \multirow{3}{*}{ Statements } & \multicolumn{6}{|c|}{ Public sector } & & \multirow{3}{*}{$\ddot{n}$} & \\
\hline & \multicolumn{2}{|c|}{$\begin{array}{l}\text { Big } \\
\text { Sector } \\
\%\end{array}$} & \multicolumn{2}{|c|}{$\begin{array}{c}\text { Middle } \\
\text { Sector } \\
\%\end{array}$} & \multicolumn{2}{|c|}{$\begin{array}{c}\text { Small } \\
\text { Sector } \\
\%\end{array}$} & 4 & & \\
\hline & 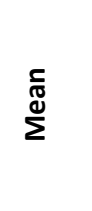 & 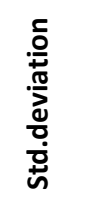 & \begin{tabular}{|l} 
足 \\
$\stackrel{\varpi}{\Sigma}$
\end{tabular} & 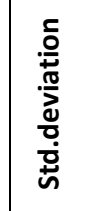 & 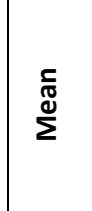 & 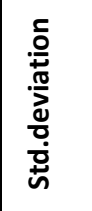 & & & \\
\hline \multicolumn{10}{|c|}{ Ontological factors affect OKCP: } \\
\hline \multicolumn{10}{|l|}{ I. $\quad$ Individual Factors: } \\
\hline \multicolumn{10}{|l|}{ 1.User Involvement: } \\
\hline a. Analysis and Design Stage & 4.09 & 0.188 & 3.76 & .502 & 3.72 & 0.732 & 3.04 & 0.053 & \\
\hline \multicolumn{10}{|l|}{ b. Implementation Stage } \\
\hline 1.Task usefulness & 4.116 & 0.341 & 3.94 & 0.643 & 4.05 & 0.564 & 0.962 & 0.380 & \\
\hline 2.General attributes & 3.6 & 0.736 & 3.75 & 0.575 & 3.56 & 0.500 & 0.757 & 0.472 & \\
\hline \multirow[t]{2}{*}{ 2.Knowledge Cognition } & 4.54 & 0.399 & 4.56 & 0.451 & 4.11 & 0.580 & $8-45$ & 0.000 & \\
\hline & 4.08 & & 4 & & 3.86 & & & & 3.89 \\
\hline \multicolumn{10}{|c|}{ II. Organizational Factors: } \\
\hline 1.Task Understanding & 3.87 & 0.397 & 3.96 & 0.527 & 3.27 & 0.944 & 9.122 & 0.000 & \\
\hline \multirow[t]{3}{*}{ 2.Information Understanding } & 3.90 & 0.172 & 3.81 & 0.947 & 3.51 & 0.603 & 2.823 & 0.065 & \\
\hline & 3.88 & & 3.57 & & 3.39 & & & & 3.67 \\
\hline & 3.98 & & 3.78 & & 3.62 & & & & 3.78 \\
\hline
\end{tabular}

Source: researcher prepared using SPSS to analyze data.

The results in Table No.6 indicated that ontological factors represented the internal environments which contain individual and organizational factors. Individual factors and organizational factors are available variously between organizational sectors: big, medium, and small sectors. The individual factors are available very high in big, high 
in both medium and small sectors. Organizational factors are available in high means in all sectors*.

Table No.8

The validation degree of $\mathrm{OKCP}$ in research community

\begin{tabular}{|c|c|c|c|c|c|c|c|c|c|}
\hline \multirow{3}{*}{ Statements } & \multicolumn{6}{|c|}{ Public sector } & \multirow{3}{*}{ 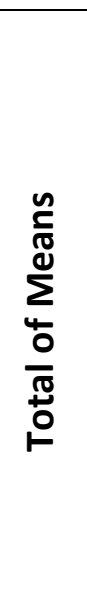 } & \multirow{3}{*}{4} & \multirow{3}{*}{$\ddot{n}$} \\
\hline & \multicolumn{2}{|c|}{$\begin{array}{c}\text { Big } \\
\text { Sector } \\
\%\end{array}$} & \multicolumn{2}{|c|}{$\begin{array}{c}\text { Middle } \\
\text { Sector } \\
\%\end{array}$} & \multicolumn{2}{|c|}{$\begin{array}{c}\text { Small } \\
\text { Sector } \\
\%\end{array}$} & & & \\
\hline & 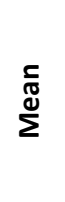 & 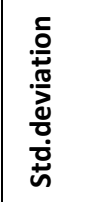 & 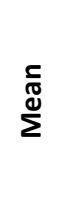 & 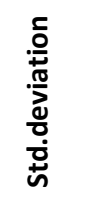 & $\begin{array}{l}\text { 䟓 } \\
\sum\end{array}$ & 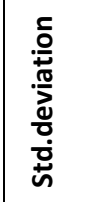 & & & \\
\hline I- $\quad$ S: Socialization & 3.74 & 0.585 & 3.44 & 0.389 & 3.08 & 0.637 & 3.42 & 10.08 & 0.000 \\
\hline II- $\quad$ E: Externalization & 3.71 & 0.440 & 3.67 & 0.719 & 3.37 & 0.712 & 3.58 & 2.56 & 0.08 \\
\hline III- C: Combination & 3.90 & 0.575 & 3.82 & 0.679 & 3.58 & 0.743 & 3.76 & 1.84 & 0.16 \\
\hline IV- I: Internalization & 3.16 & 1.009 & 3.22 & 0.698 & 3.62 & 0.739 & 3.33 & 3.22 & 0.04 \\
\hline Total & 3.62 & & 3.53 & & 3.41 & & 3.3.52 & & \\
\hline
\end{tabular}

Source: researcher prepared using SPSS to analyze data.

The results in Table No.8 indicated that OKCP are socialization, externalization, combination, and internalization. These processes are available highly in all sectors. Also all processes are validated highly except Internalization process is validated; this is because organizations have not a fixed strategy to publish personal knowledge between the employees, and do not care with keep in tacit knowledge and converting to explicit knowledge to tacit knowledge.

Table.9d displayed the relationship between individual Factors and socialization; that is to defined the impact of ontological factors on OKCP.

\footnotetext{
* The questionnaire is a fifth scale, so the range of scale $=\mathrm{N}-1 \backslash \mathrm{N}=5-1 \backslash 5=0.8$, So the scales are:5- more * than 4.2 very high, 4.2- more than 3.4 high, 3.4 - more than 2.6 medium, 2.6- more than 1.8 low, 1.8more than 1 very low.
} 
Table. 9

The relationship between individual Factors and socialization

\begin{tabular}{|l|l|l|l|}
\hline Sectors & Correlation & $\mathrm{R}^{2}$ & Sig. \\
\hline Big & 0.864 & 0.746 & 0.000 \\
\hline Medium & 0.820 & 0.672 & 0.000 \\
\hline Small & 0.790 & 0.624 & 0.000 \\
\hline
\end{tabular}

Source: researcher prepared using SPSS to analyze data.

Table .9 illustrated a significant correlation relationship between individual factors and socialization process in all organizations 'sectors. Correlation values in big, medium, and small sector were $0.864,0.820,0.790$ sequins. So socialization process is a function in individual factors, and then individual factors explained the changes in socialization process with $74.6 \%$ in big sector, $67.2 \%$ in medium sector, and $62.4 \%$ in small sector. Also table .9 displayed a variance between the validation degrees to variables between the three sectors in research community. That is because all statistical significant is less than 0.05 .

Table. 10

The relationship between individual Factors and Externalization

\begin{tabular}{|l|l|l|l|}
\hline Sectors & Correlation & $\mathrm{R}^{2}$ & Sig. \\
\hline Big & 0.899 & 0.808 & 0.000 \\
\hline Medium & 0.817 & 0.667 & 0.000 \\
\hline Small & 0.780 & 0.608 & 0.000 \\
\hline
\end{tabular}

Source: researcher prepared using SPSS to analyze data.

Table .10 illustrated a significant correlation relationship between individual factors and externalization process in all organizations 'sectors. Correlation values in big, medium, and small sector were $0.899,0.817,0.780$ sequins. So externalization process is a function in individual factors, and then individual factors explained the changes in socialization process with $80.8 \%$ in big sector, $66.7 \%$ in medium sector, and $60.8 \%$ in small sector. Also table .9 displayed a variance the validation degrees to variables between the three sectors in research community, that is because all statistical significant is less than 0.05 .

Table.11

The relationship between individual Factors and combination

\begin{tabular}{|l|l|l|l|}
\hline Sectors & Correlation & $\mathrm{R}^{2}$ & Sig. \\
\hline Big & 0.890 & 0.792 & 0.000 \\
\hline Medium & 0.812 & 0.659 & 0.000 \\
\hline Small & 0.786 & 0.617 & 0.000 \\
\hline
\end{tabular}

Source: researcher prepared using SPSS to analyze data. 
Table .11 illustrated a significant correlation relationship between individual factors and combination process in all organizations 'sectors. Correlation values in big, medium, and small sector were $0.890,0.812,0.786$ sequins. So socialization process is a function in individual factors, and then individual actors explained the changes in socialization process with $97.2 \%$ in big sector, $65.9 \%$ in medium sector, and $61.7 \%$ in small sector. Also table .9 displayed a variance between the validation degrees to variables between the three sectors in research community, that is because all statistical significant is less than 0.05 .

Table. 12

The relationship between individual Factors and Internalization

\begin{tabular}{|l|l|l|l|}
\hline Sectors & Correlation & $\mathrm{R}^{2}$ & Sig. \\
\hline Big & 0.840 & 0.705 & 0.000 \\
\hline Medium & 0.807 & 0.651 & 0.000 \\
\hline Small & 0.792 & 0.627 & 0.000 \\
\hline
\end{tabular}

Source: researcher prepared using SPSS to analyze data.

Table .12 illustrated a significant correlation relationship between individual factors and internalization process in all organizations 'sectors. Correlation values in big, medium, and small sector were $0.840,0.807,0.792$ sequins. So socialization process is a function in individual factors, and then individual actors explained the changes in socialization process with $70.5 \%$ in big sector $65.1 \%$ in medium sector, and $62.7 \%$ in small sector. Also table .9 displayed a variance between the validation degrees to variables between the three sectors in research community, that is because all statistical significant is less than 0.05 .

Table.13

The relationship between Organizational Factors and Socialization

\begin{tabular}{|l|l|l|l|}
\hline Sectors & Correlation & $\mathrm{R}^{2}$ & Sig. \\
\hline Big & 0.822 & 0.675 & 0.000 \\
\hline Medium & 0.802 & 0.643 & 0.000 \\
\hline Small & 0.770 & 0.592 & 0.000 \\
\hline
\end{tabular}

Source: researcher prepared using SPSS to analyze data.

Table .13 illustrated a significant correlation relationship between organizational factors and socialization process in all organizations 'sectors. Correlation values in big, medium, and small sector were $0.822,0.802,0.770$ sequins. So socialization process is a function in individual factors, and then individual actors explained the changes in socialization process with $67.5 \%$ in big sector, $64.3 \%$ in medium sector, and $59.2 \%$ in small sector. Also table .9 displayed a variance between the validation degrees to variables between the three sectors in research community, that is because all statistical significant is less than 0.05 . 
Table. 14

The relationship between Organizational Factors and Externalization

\begin{tabular}{|l|l|l|l|}
\hline Sectors & Correlation & $\mathrm{R}^{2}$ & Sig. \\
\hline Big & 0.842 & 0.708 & 0.000 \\
\hline Medium & 0.811 & 0.657 & 0.000 \\
\hline Small & 0.775 & 0.600 & 0.000 \\
\hline
\end{tabular}

Source: researcher prepared using SPSS to analyze data.

Table .14 illustrated a significant correlation relationship organizational factors and externalization process in all organizations 'sectors. Correlation values in big, medium, and small sector were $0.842,0.811,0.775$ sequins. So socialization process is a function in individual factors, and then individual actors explained the changes in socialization process with $70.8 \%$ in big sector, $65.7 \%$ in medium sector, and $60 \%$ in small sector. Also table .9 displayed a variance between the the validation degrees to variables between the three sectors in research community, that is because all statistical significant is less than 0.05 .

Table. 15

The relationship between Organizational Factors and Combination

\begin{tabular}{|l|l|l|l|}
\hline Sectors & Correlation & $\mathrm{R}^{2}$ & Sig. \\
\hline Big & 0.862 & .743 & 0.000 \\
\hline Medium & 0.807 & 0.651 & 0.000 \\
\hline Small & 0.762 & 0.580 & 0.000 \\
\hline
\end{tabular}

Source: researcher prepared using SPSS to analyze data.

Table .15 illustrated a significant correlation relationship between organizational factors and combination process in all organizations 'sectors. Correlation values in big, medium, and small sector were $0.862,0.807,0.762$ sequins. So socialization process is a function in individual factors, and then individual actors explained the changes in socialization process with $74.3 \%$ in big sector, $65.1 \%$ in medium sector, and $58 \%$ in small sector. Also table .9 displayed a variance between the validation degrees to variables between the three sectors in research community, that is because all statistical significant is less than 0.05 .

Table.16

The relationship between Organizational Factors and Internalization

\begin{tabular}{|l|l|l|l|}
\hline Sectors & Correlation & $\mathrm{R}^{2}$ & Sig. \\
\hline Big & 0.872 & 0.760 & 0.000 \\
\hline Medium & 0.803 & 0.644 & 0.000 \\
\hline Small & 0.752 & 0.565 & 0.000 \\
\hline
\end{tabular}

Source: researcher prepared using SPSS to analyze data. 
Table .16 illustrated a significant correlation relationship between organizational factors and internalization process in all organizations 'sectors. Correlation values in big, medium, and small sector were $0.872,0.803,0.752$ sequins. So socialization process is a function in individual factors, and then individual actors explained the changes in socialization process with $76 \%$ in big sector, $64.4 \%$ in medium sector, and $56.5 \%$ in small sector. Also table .9 displayed a variance between the validation degrees to variables between the three sectors in research community, that is because all statistical significant is less than 0.05 .

\section{Discussion and conclusion}

This study investigated the factors that affect initiating organizational knowledge creation process; this study specifies the possible impact of ontological factors internal environment (individual and organizational factors) on each component of the knowledge creation process (SECI).

Researcher conducted empirical study which based on 90 respondents from organizations in pharmaceutical's industries, In order to investigate the factors that affect initiating OKCP which in turn help creating organizational knowledge. Researcher employed mean, correlation, one-way ANOVA, and regression analysis using SPSS package. The research results support the theoretical framework. The statistical results are shown in tables 6-16. In the former tables, the composite effect of organizational knowledge creation processes is influenced by individual and organizational factors.

\section{Theoretical implication}

Table.17 illustrated results of hypothesis test.

Table. 17

Results of Hypothesis test

\begin{tabular}{|l|c|c|}
\hline \multicolumn{1}{|c|}{ Hypothesis } & Result & Reference \\
\hline $\begin{array}{l}\text { Hypothesis 1: There are statistically significant } \\
\text { differences between the degrees of validation of } \\
\text { ontological factors between organizations 'sectors. }\end{array}$ & Yes & Tables 7 \\
\hline $\begin{array}{l}\text { Hypothesis2: There are statistically significant } \\
\text { differences between the degrees of validation of } \\
\text { organizational knowledge creation processes OKCP } \\
\text { between organizations' sectors. }\end{array}$ & Yes & Table 8 \\
\hline $\begin{array}{l}\text { Hypothesis 3: There is a probability to have a significant } \\
\text { correlation relationship between ontological factors and } \\
\text { OKCP; socialization, externalization, combination, } \\
\text { internalization in various organizations sectors. }\end{array}$ & Yes & Table 9-16 \\
\hline $\begin{array}{l}\text { Hypothesis 4: There is a probability to be an ontological } \\
\text { factors impact on OKCP in various organizations sectors. }\end{array}$ & Yes & Table 9-16 \\
\hline
\end{tabular}

Source: Developed by the researcher. 


\section{Managerial implication}

According to theoretical and empirical study there are four modes of knowledge conversion:

1. Socialization (from tacit knowledge to tacit knowledge);

2. Externalization (from tacit knowledge to explicit knowledge);

3. Combination (from explicit knowledge to explicit knowledge); and

4. Internalization (from explicit knowledge to tacit knowledge).

These four modes of knowledge conversion form a spiral of the SECI processes. Knowledge created through this spiral process can trigger a new spiral of knowledge creation, expanding horizontally and vertically across organizations. This interactive spiral process takes place both intra- and inter-organization. One example is the articulation of tacit knowledge possessed by customers that they themselves have not been able to articulate. A product works as the trigger to elicit tacit knowledge when customers give meaning to the product by purchasing, adapting, using, or even not purchasing it. Their actions are then reflected in organization and a new spiral of organizational knowledge creation begins again (Nonaka, 1991, Nonaka et al., 2000).

Depending on ontological; SECI will be initiated and lead to create knowledge in different forms and various characteristics. Fig.2 displayed that ontological factors reflect the internal environment that includes individual and organizational factors, and these factors in turn initiating the process of organizational knowledge creation which lead to create the knowledge in the organization either tacit or explicit knowledge. 


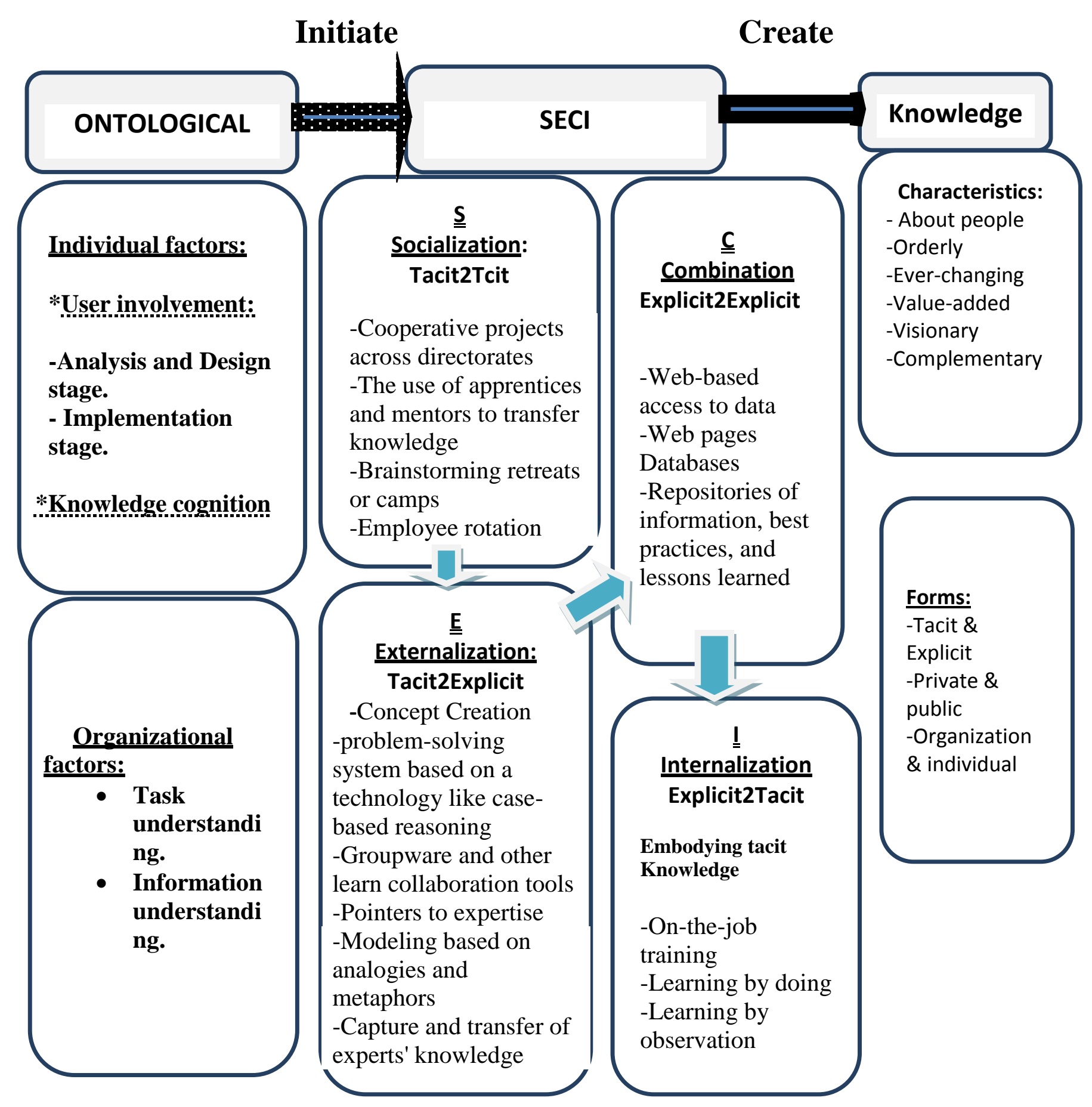

Fig. 2 Factors affect OKCP Model

Source: developed by the researcher 


\section{References}

1. Bagozzi RP, Yi Y.( 1988). "On the evaluation of structural evaluation models". J Acad. Mark Sci;16(1):74-94.

2. Baker J, Parasuraman A, Grewal D, Voss GB. (2002). "The influence of multiple store environment cues on perceived merchandise value and patronage". intentions Mark;66(2):120-41.

3. Barki H. and J. Hartwick,(1994). "Measuring user participation, user involvement, and user attitude". MIS Quarterly 18(1) (1994) 59-82.

4. Becerra-Fernandez I, Sabherwal R.( 2001)." Organizational knowledge management: a contingency perspective". J Manage Inf Syst;18(1):23-55.

5. Bucklin LP, Sengupta S.( 1993). "Organizing successful co-marketing alliance's. J Mark ;57(2):32-46.

6. Chang ,Jaegyong; Choi, Byounggu and Lee , Heeseok . (2011). " An organizational memory for facilitating knowledge: an application to e-business architecture". Expert Systems with Applications. 26 , 203-215.

7. Chia R. (2003)." From knowledge-creation to the perfecting of action: Tao, Basho and pure experience as the ultimate ground of knowing". Hum Relat;56 (8):953-81.

8. Choi, Byounggu and Lee , Heeseok . (2002)." Knowledge management strategy and its link to knowledge creation process". Expert Systems with Applications. $23,173-187$.

9. Chou ,Shih-Wei and He ,Mong-Young.( 2004)."Knowledge Management: The Distinctive Roles of Knowledge Assets in Facilitating Knowledge creation".Journal of Information Science, 30 (2) pp. 146-164.

10. Chou ,Shih-Wei and Tsai, Yu-Hung .( 2004). "Knowledge creation: individual and organizational perspectives".Journal of Information Science, 30 (3), pp. 205-218.

11. Ciborra ,C.U.,(1991). "From thinking to tinkering: the grassroots of strategic information systems". In: J.I. DeGross, I.Benbasat, G. DeSanctis, and C.M. Beath (eds), Proceedings of the Twelfth International Conference on Information Systems, New York.

12. Davenport, T.H., Prusak, L., 1998. Working Knowledge. Harvard Business.

13. De Alwis , RagnaSeidler- and Hartmann, Evi. ( 2008)." The use of tacit knowledge within innovative companies: knowledge management in innovative enterprises". Journal of Knowledge Management.VOL.12 NO. 1.

14. Droge C, Claycomb C, Germain R. (2003). Does knowledge mediate the effect ofcontext on performance? Some initial evidence. Decis Sci;34(3):54168.

15. Foster Jr. ,S. Thomas and Franz Charles R. (1999)." User involvement during information systems development: a comparison of analyst and userperceptions of system acceptance". Journal of Engineering And Technology Management. 16, 329-348.

16. Gold AH, Malhotra A, Segars AH. (2001). "Knowledge management: an organizational capabilities perspective". J Manage Inf Syst; 18(1):185-214.

17. Hoegl, Martin and Schulze,WhuAnja .( 2005). "How to Support Knowledge Creation in New Product Development: An Investigation of Knowledge Management Methods".European Management Journal. Vol. 23, No. 3, pp. 263-273. 
18. Huber, George (1991). 'Organizational learning: The contributing process and the literature'. Organization Science 2/1: 88-115.

19. Jimenez, Daniel Jimenez and Valle , Raquel Sanz-.( (2012)." Studying the effect of HRM practices on the knowledge management process".Personnel Review, Vol. 42 Iss: 1.

20. Kahlil, Gibran. (2004). THE Knowledge Management Cycle : knowledge management processes at individual, group, and organizational . New York: Doubleday. 1883-1931.

21. Kale, P., Singh, H., 1999. Alliance capability and success: a knowledge based

22. King,W.R. and T. Teo,(1994)." Facilitators and inhibitors for the strategic use of information technology". Information and Management. 27(2) 71-81.

23. Kogut, B., \& Zander, U. (1992). "Knowledge of the firm, combinative capabilities, and the replication of technology". Organisation Science, 3, 383-397.

24. Lang, J. C. (2001). "Managerial concerns in knowledge management". Journal of Knowledge Management, 5, 43-57.

25. Langton,Helen ; Barnes,Mary ; Haslehurst,Susan ; Rimmer, James ; and Turton Pat ( 2003)." Collaboration, user involvement and education: a systematic reviewof the literature and report of an educational initiative". European Journal of Oncology Nursing. 7 (4), 242-252.

26. Lee a ,Kun Chang, ${ }^{*}$, Lee b ,Sangjae, and Kangc ,In Won. ((2005)."KMPI: measuring knowledge management performance". Information \& Management. 42, 469-482.

Lee, Wei-Long ; Lee, Mei-Chi ; Lin, Lee - Hsuan ; and Huang ,Hao-Chen (2011)." Value creation potential of individual and organizational memory in health care services". Expert Systems with Applications.38 , 10658-10664.

27. Leonard, D., Sensiper, S., 1998. The role of tacit knowledge in group innovation. California Management Review 40 (3), 112-132. levels. Decis Sci;34(2):225-60.

28. Liebowitz,Jsy and Megbolugbe,Isaac (2003). "A set of framework to aid the project manager in conceptualizing and implementing knowledge management initiative". International Journal of Project Management. 21,189-198.

29. Martensson,Maria (2000). "A critical review of knowledge management as a management tool". Journal of Knowledg Management. 4, 3, 2000, 204-216.

30. Matusik SF, Hill CWL.(1998). The utilization of contingent work, knowledge creation, and competitive advantage. Acad Manage Rev; 23(4):680-97.

31. Mortazavi, S.Habib and Bahrami ,Mahdi (2012)." Integrated Approach to Entrepreneurship - Knowledge based Economy: A Conceptual Model". Procedia - Social and Behavioral Sciences 41,281 - 287.

32. Nambisan, S. R. Agarwal, and M. Tanniru, (1999). "Organisational mechanisms for enhancing user innovation in information technology". MIS Quarterly. 23(3) 365-395.

33. Nonaka I, Konno N. (1998). The concept of "ba": building a foundation for knowledgecreation. California Management Review;40(3):40-54.

34. Nonaka I, Takeuchi H, Umemoto K. (1996). A theory of organizational knowledgecreation. Int J Technol Manag;11(7):833-45.

35. Nonaka I, Takeuchi H. (1995). The knowledge-creating company: how Japanesecompanies create the dynamic of innovation. New York: Oxford University Press. 
36. Nonaka I, Toyama R, Konno N. (2000b). "SECI, Ba and leadership: a unified model ofdynamic knowledge creation". Long Range Plan;33(1):5-34.

37. Nonaka I, Toyama R, Nagata A.(2000a). " A firm as a knowledge-creating entity: a newperspective on the theory of the firm". Ind Corp Change;9(1):120.

38. Nonaka I. (1994). "A dynamic theory of organizational knowledge creation". Organ Sci;5(1):14-37.

39. Nunnally JC.(1986). Psychometric theory. New York: McGraw-Hill; 1978.

40. P.H. Gray,( 2000)." The effects of knowledge management systems on emergent teams: towards a research model". Journal of Strategic Information Systems 9, pp. 175-191.

Podsakoff PM, OrganDW. Self-reports in organizational research: problems and prospects. J Manage;12(4):531-44.

41. Polanyi, M. (1966). Tacit Dimension, Doubleday, New York, NY.

42. Sabherwal R, Becerra-Fernandez I.(2003). "An empirical study of the effect of knowledge management processes at individual group and organizational levels". DecisSci; 34(2);225-60.

43. Sabherwal, R. and Sabherwal, S. (2005), "Knowledge management using information technology: determinants of short-term impact on firm value", Decision Sciences, Vol. 36 No. 4, pp. 531-67.

44. Schulzea ,Anja and Hoegl , Martin, (2008)."Organizational knowledge creation and the generation of new product ideas: A behavioral approach". Research Policy.( 37), 1742-1750.

45. Sherif, C.W. M. Sherif, and R.E.( 1965). Nebergall (eds), Attitude and Attitude Change . Saunders, Philadelphia.

46. $\quad$ Song, JiHoon . Uhm, Daiho and Yoon ,Seung Won. (2011)." Organizational knowledge creation practice".Leadership\& Organization Development Journal. Vol. 32 No. 3, ,pp. 243-259.

47. Tsai 1, Ming-Tien, and Li Yong-Hui. (2007). "Knowledge creation process in new venture strategy and performance". Journal of Business Research. 60 ,371-381

48. W.R. King and D. Ko, (2001)." Evaluating knowledge management and the learning organisation: an information/ knowledge value chain approach". Communications of the Association for Information Systems 5(14) 1-26.

49. Wang, Dong . Su ,Zhongfeng .and Yang ,Dongtao. ( 2011). "Organizational culture and knowledge creation capability". Journal OF Knowledge Management, Vol. 15 No. 3, pp. 363-373.

50. Yang, M.G., Hong, P. and Modi, S.B. (2011), "Impact of lean manufacturing and environmental management on business performance: An empirical study of manufacturing firms",International Journal of Production Economics, Vol. 129 No. 2, pp. 251-61.

51. Yanga,Chen-Wei .Fangb,Shih-Chieh and Linc, Julia L. (2010). Organisational knowledge creation strategies: A conceptual framework ". International Journal of Information Management. 30 , 231-238.

52. Zack M. (1999). Developing a knowledge strategy. Calif Manage Rev;41(3):125-46. 


\section{العوامل المؤثرة على عمليات خلق المعرفة في البيئة الصناعية المصرية: \\ دراسة مقارنة}

ملخص البحث

تز ايد الاهتمام في الآونة الأخيرة بإدارة المعرفة والتي تتكون من ست عمليات رئيسية

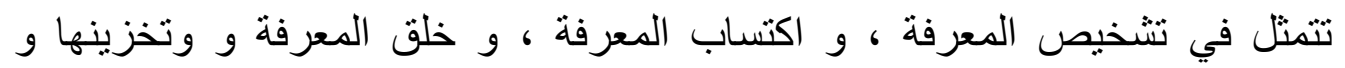
توزيعها ثم تطبيق المعرفة. هذا وقد قامت الباحثة بدراسة عملية خلق المعرفة باعتبار ها

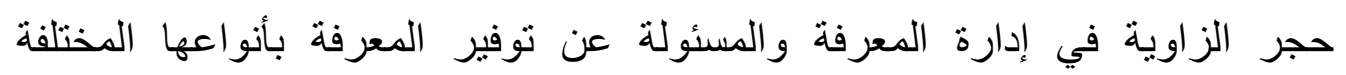

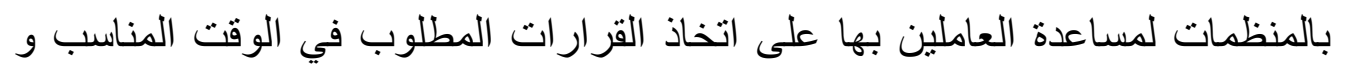

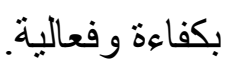

و من ثم تم تناول إدارة المعرفة بالدراسة من خلال محاولة الوقوف على أثر

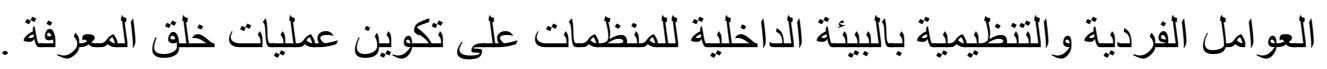

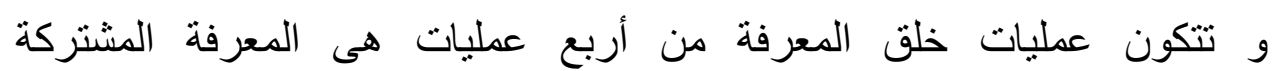
Socialization العاملين إلى معرفة ضمنية مشتركة بين جميع العاملين، ثم عملية المعرفة الخارجية المجسدة Externalization وهي مسئولة عن تحويل المعرفة الضمنية إلى معرفة صريحة موثقة ومحفوظة بمستندات، يلي ذلك عملية المعرفة التركيبية Combination أكبر و أوسع انتشاراً بالمنظمة وبين العاملين بها، و تتمثل آخر عمليات خلق المعرفة في لئي عملية المعرفة الداخلية ( المدمجة ) Internalization وهى مسئولة عن تحويل ولهيل

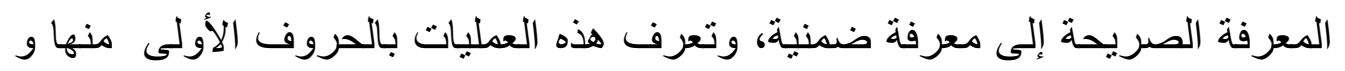
هى SECI ؛ و تفيد هذه العمليات في تكوين و توليد المعرفة بنو عيها الصريحة و الضمنية بالمنظمات المختلفة.

لقد تم تقسيم العوامل الفردية إلى بعدين رئيسيين، هما مشاركة المستخدم في خلق بلق القيطي

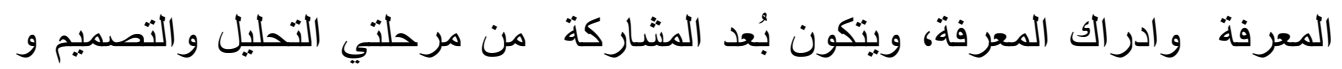

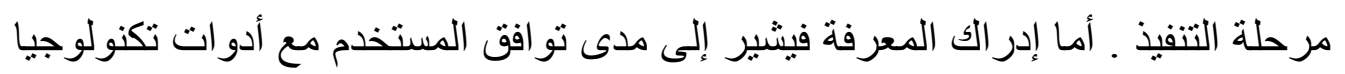

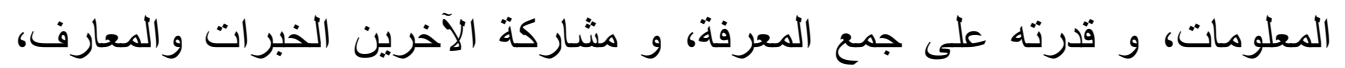

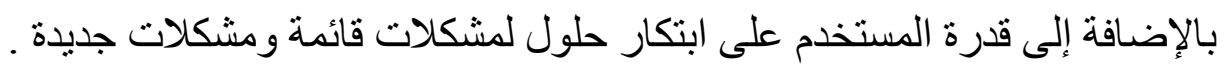


أما العوامل التنظيمية فتشتمل على بعدين رئيسيين هما فهم مهام العمل وفهم

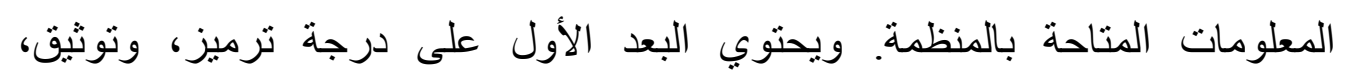
و الحصول على المعارف بشكل موحد ومرمز، ومشاركة المعرفة باستخدام نظام

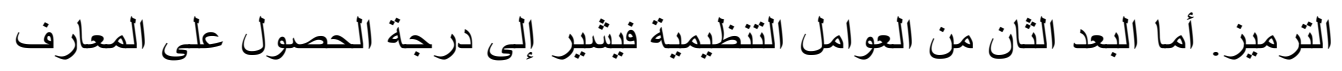

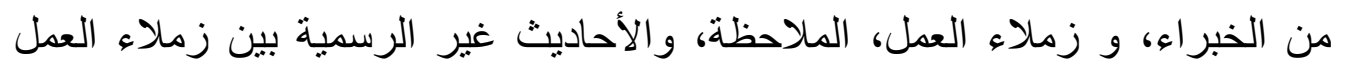
بهدف مشاركة المعرفة. وقد تم تطبيق البحث على عدد .9 مفردة بالمنظمات العاملة في مجال الصناعات الدوائية بمدينة العانشر من رمضان. وتم تقسيم تلك المنظمات إلى قطاعات ثنلاثة وفقاً

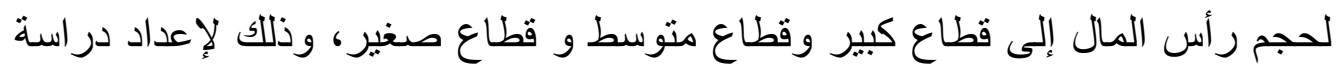

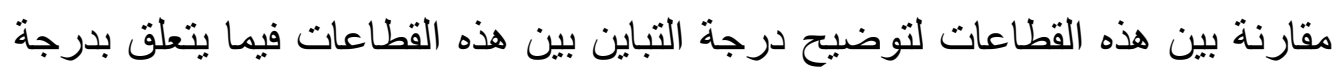

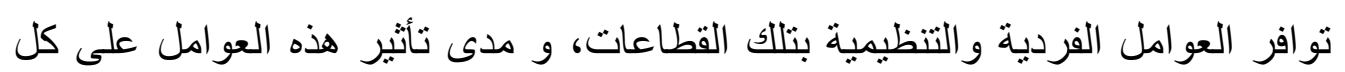

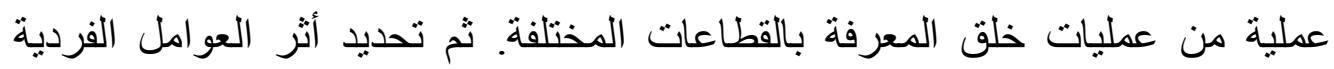
و العو امل على التنظيمية على عمليات خلق المعرفة بالمنظمات جهة البحث. توصل البحث إلى نوافر كل من العوامل الفردية والتظظيمية بالقطاعات الثلاثة

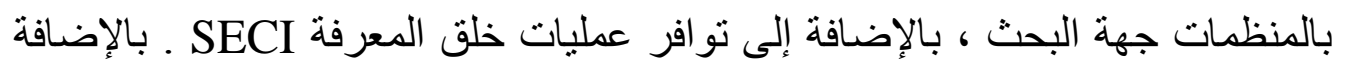
إلى وجود نأثير قوي للعوامل الفردية والتنظيمية على عمليات خلق المعرفة ؛ ومن ثمالثم يجب على الإدارة العليا بالمنظمات تعزيز العوامل الفردية والعوامل التنظيمية التي يتطلبها تكوين عمليات إدارة المعرفة الأربع؛ و ذلك لضمان لإندان خلق المعرفة التنظيمية اللازمة لبناء نظام متكامل لإدارة المعرفة. 